\title{
KESESUAIAN SOSIAL EKONOMIPERLINDUNGAN LAHAN PERTANIAN PANGAN BERKELANJUTAN DI KABUPATEN KUNINGAN
}

\author{
Socio Economic Suitability of Land Preservation Program in Kuningan Regency
}

Danang Pramudita*), Arya Hadi Dharmawan dan Baba Barus

Program Studi Ilmu Perencanaan Pembangunan Wilayah dan Perdesaan, Fakultas Ekonomi dan Manajemen, IPB

*E-mail : dannpramudita@gmail.com

\begin{abstract}
Economic development in Indonesia since 1980s is dealing with conversion of agricultural land to industry, housing, and other sector in city and its periphery. Land conversion have a great impact to food production rather than the impact from technical problem (drought and pest problem). Government need to preserve agricultural land in order to maintain food production. Thus government made a mandatory approach byissued Law No. 41 year 2009. The aim of this research are to identify an actual socioeconomic characteristics in the area of land preservation program (LP2B) in Kuningan Regency, to identify farmers perception on LP2B and to analyze socioeconomic suitability in the areaof $L P 2 B$ program. Data were analyzed by descriptive statistics and likert scale. Based on the result, there are nine socioeconomic indicator on land preservation program (LP2B) in Kuningan Regency, namely; land conversion rate, food balance, disparity between farm and non-farm income, agriculture households, agriculture labor, farmers' groups, spatial planning policies and farmers perceptions. Farmers have a positive perception on LP2B program. Land preservation program (LP2B) priority should be donein Cilimus sub district due to low support of socio economic characteristic. Meanwhile Ciawigebang and Cibingbin sub district become a next priority of preservation.
\end{abstract}

Keyword: farmer's perception, food security, land conversion, socioeconomic of $L P 2 B$

\section{PENDAHULUAN}

Pembangunan perkotaan di Indonesia selama periode ledakan ekonomi tahun 1980-1990 ditandai dengan perubahan penggunaan lahan pertanian primer menjadi industri, perumahan, dan penggunaan lain pada daerah kota dan sekitarnya (Firman, 2004). Sebagian besar magnitude prosesalihfungsi lahan berlangsung, khususnya pada kawasan-kawasan perbatasan kota-desa dan perbatasan kawasan budidaya-non budidaya (Rustiadi2001). Pasca krisis moneter dan seiring dengan berjalannya proses otonomi daerah proses konversi lahan pertanian tidak hanya terjadi disekitar daerah perkotaan tapi meluas ke wilayah lainnya dengan skala konversi yang lebih luas. Konversi lahan pertanian dipengaruhi oleh banyak faktor yang cenderung kompleks. Menurut Irawan (2005) dari

Sudut pandang ekonomi konversi lahan pertanian disebabkan oleh tarikan permintaan lahan untuk kegiatan non pertanian dan dorongan petani pemilik lahan. Perilaku permintaan dan penawaran lahan tidak terlepas dari kebijakan pembangunan ekonomi, sosial, dan sarana publik sehingga fenomena konversi lahan tidak terlepas pula dari kebijakan yang ditempuh pemerintah.

Konversi lahan merupakan konsekuensi yang dihadapi oleh negara yang sedang berkembang seperti Indonesia. Badan Pertanahan Nasional Republik Indonesia mencatat dari tahun 1990 hingga 2009 rata-rata 18.745 hektar sawah per tahun terkonversi ke penggunaan lain.Penurunan luas penggunaan sawah terbesar terjadi di Pulau Kalimantan dan Pulau Jawa, sedangkan penambahan sawah terbesar berada di Pulau Sumatera dan Pulau Sulawesi. Proses ini terjadi sebagai dampak dari peningkatan aktivitas ekonomi dalam pemanfaatan sumber daya dan akibat diberlakukannya hukum pasar (ekonomi klasik). Hukum pasar memicuadanya pergeseran aktivitas pada lahan dari aktivitas yang menghasilkan keuntungan rendah (land rent) menuju aktivitas-aktivitas dengan land rent yang lebih tinggi (Rustiadi 2001). Posisi pertanian dalam menghasilkan rente lahan cenderung kalah dengan sektor lain seperti industri, perumahan,dan jasa.Land rent pertanian nilainya 1:500 untuk kawasan industri dan 1:622 untuk kawasan perumahan (Nasoetion dan Winoto, 1996), kondisi ini menyebabkan aktivitas alih fungsi lahan menjadi tidak terkendali terutama pada wilayah sekitar perkotaan. Lebih lanjut Rustiadi (2001) menyatakan kondisi ini disebabkan distorsi pada nilai lahan yang ditentukan oleh expected value-nya, serta harga pasar yang berlaku tidak menyertakan ekseternalitas positif dari lahan pertanian (environment rent).

Upaya penyelamatan lahan pertanian pangan dilakukan Pemerintah dengan menerbitkan Undang-Undang No. 41 tahun 2009 tentang perlindungan Lahan Pertanian Pangan Berkelanjutan (LP2B). Perlindungan LP2Bdilakukan dengan mengidentifikasi lahan pertanian yang ada, baik 
yang beririgasi teknis maupuntidak beririgasi, serta lahan potensial untuk produksi pertanian.Setelah diinventarisasi, lahan tersebut ditetapkan sebagai Lahan Pertanian Pangan Berkelanjutan (LP2B) dan Lahan Cadangan Pertanian Pangan Berkelanjutan (LCP2B) baik di dalam maupun di luar Kawasan Pertanian Pangan Berkelanjutan (KP2B). Penetapan KP2B menjadi bagian integral Rencana Tata Ruang Wilayah Kabupaten, sedangkan LP2B dan LC2B diintegrasikan dalam Rencana Tata Ruang rinci.

Sebelum muncul UU No. 41 tahun 2009 sebenarnya pemerintah telah secara eksplisit melakukan perlindungan terhadap lahan pertanian melalui UUPA No 50 tahun 1960, UU No 12 tahun 1992 tentang sistem budidaya tanaman, UU No 26 tahun 2007 tentang penataan ruang, serta peraturan presiden dan peraturan pemerintah lainnya. Fakta dilapangan menunjukkan pengendalian konversi lahan sawah melalui pendekatan yuridis belum maksimal dalam mengatasi permasalahan konversi lahan. Laju konversi lahan sawah masih cukup besar bahkan merambah ke lahan sawah dengan irigasi teknis yang sangat potensial untuk produksi padi sawah (Irawan, 2008).

Program perlindungan lahan pertanian pangan berkelanjutan yang diamanatkan dalam UU No. 41 tahun 2009 merupakan program yang bersifat wajib (mandatory) dan diintegrasikan dengan perda RTRW.Tantangan dalam penerapan program perlindungan lahan pertanian pangan yang bersifat mandatory dan komprehensif ialah tingginya biaya pelaksanaan serta prosesnya yang cukup kompleks. Seperti diungkapkan Furuseth and Pierce (1982) dalam proses perlindungan lahan pangan secara mandatory, komponen pembiayaan yang utama adalah proses pendefinisian dan identifikasi sumber daya lahan yang harus dilindungi serta penciptaan sistem administrasi untuk menjamin kebijakan tersebut dapat diimplementasikan dan diawasi.

Saat ini perlindungan lahan pertanian pangan berkelanjutan sebagian besar berada pada tahapan identifikasi untuk usulan LP2B. Sebagian besar proses identifikasi LP2B baru pada tahapan penetapan luasan LP2B di kabupaten/kota dan belum menetapkan secara jelas posisi ruang dari LP2B yang akan dilindungi. Meskipun data berbasis citra sudah tersedia, pengembangan model spasial lahan pertanian pangan berkelanjutan dengan menggunakan data spasial masih perlu dilengkapi. Data penggunaan lahan terkait dengan sosial dan ekonomidiperlukan untuk menjamin suatu lahan akan dilindungi khususnya oleh pemilik lahan dan merupakan kebutuhan masyarakat (Barus et al, 2012). Lebih rinci (Barus et al, 2012) menyatakan data yang terkait dengan persepsi petani membantu menjelaskan harapan pemilik/ pengelola lahan dari sisi budaya, ekonomi dan lingkungan. Data produktivitas usahatani, indeks pertanaman, biaya proses pengolahan, tenaga kerja, pemupukan dan lain-lain diperlukanuntuk penghitungan penerimaan usahatani. Selain itu data demografi juga dipakai untuk menentukanstatus defisit dan surplus pangan di lokasi. Indikator dari aspek sosial dan ekonomi dalam perlindungan lahan pangan berkelanjutan termasuk ke dalam aspek institusional. Aspek institusional merupakan aspek yang lebih kompleks dalam penanganannya. Seperti dikemukakan Ding and Lichtenberg (2008), rintangan terbesar dalam perlindungan lahan pangan bukan pada aspek fisik melainkan institusional. Kegagalan dalam mengatur aspek institusional berpengaruh terhadap permintaan dan penawaran lahan untuk dikonversi. Penyelesaian masalah ini perlu didukung keinginan petani untuk mempertahankan lahan.

\section{METODE PENELITIAN}

Desain penelitian yang digunakan adalah desain kuantitatif dengan menggunakan statistik deskriptif dan model dinamik yang didukung data kualitatif untuk analisisnya. Data yang digunakan dalam penelitian terdiri dari data primer dan data sekunder. Data sekunder diperoleh dari instansi terkait seperti Bappeda, BPS, BP4K, dan Dinas Pertanian, Peternakan dan Perikanan Kabupaten Kuningan. Sedangkan untuk data primer, proses pengumpulan data menggunakan teknik survei dengan instrumen wawancara dan kuisioner.

Penelitian dilakukan pada lahan sawah di Kabupaten Kuningan, Provinsi Jawa Barat. Penelitian dilaksanakan di Kecamatan Ciawigebang, Kecamatan Cilimus dan Kecamatan Cibingbin yang merupakan kecamatan dengan luas usulan LP2B yang cukup besar dan mewakili beberapa kawasan di Kabupaten Kuningan. Kecamatan Ciawigebang merupakan akses jalur menuju Jawa Tengah, Kecamatan Cilimus merupakan akses jalan menuju Pantura khususnya Cirebon, sedangkan Kecamatan Cibingbin berada di luar akses jalan utama. Pertimbangan pengambilan lokasi sampel penelitian memperhatikan kemungkinan tingkat

Tabel 1 Indikator penentuan lokasi penelitian

\begin{tabular}{llll}
\hline \multicolumn{1}{c}{ Indikator Penentuan } & $\begin{array}{c}\text { Kecamatan } \\
\text { Cilimus }\end{array}$ & $\begin{array}{c}\text { Kecamatan } \\
\text { Ciawigebang }\end{array}$ & Kecamatan Cibingbin \\
\hline Luas usulan LP2B & $922,38 \mathrm{ha}$ & $1.382,31 \mathrm{ha}$ & $702,37 \mathrm{ha}$ \\
Produktivitas Padi & $61,39 \mathrm{kwt} / \mathrm{ha}$ & $60,29 \mathrm{kwt} / \mathrm{ha}$ & $59,49 \mathrm{kwt} / \mathrm{ha}$ \\
Jarak ke ibukota kabupaten & $7,39 \mathrm{~km}$ & $13,8 \mathrm{~km}$ & $34,34 \mathrm{~km}$ \\
TK pertanian & $29,63 \%$ & $12,93 \%$ & $36,76 \%$ \\
Kepadatan penduduk & $1.621 / \mathrm{km}^{2}$ & $1.676 / \mathrm{km}^{2}$ & $617 / \mathrm{km}^{2}$ \\
Keluarga pra sejahtera & $2,19 \%$ & $1,96 \%$ & $6,52 \%$ \\
\hline
\end{tabular}

Sumber : Kuningan dalam angka 2012 \& Suseda 2012 (diolah) 
konversi, luas hamparan, serta proporsi jumlah petani pemilik dan penggarap (Tabel 1). Pengambilan data dilakukan dari bulan Agustus sampai Desember 2014.

\section{Analisis Persepsi Petani}

Persepsi petani dilihat melalui beberapa item yang terkait dengan usaha petani untuk melindungi lahan pertanian pangan berkelanjutan. Item yang ditanyakan mencakup, 1) peran lahan pertanian yang diusahakan; 2) perlunya perlindungan terhadap lahan pertanian; 3) keinginan untuk mengkonversi lahan; 4) keinginan untuk menjual lahan; 5) keinginan untuk mempertahankan lahan ketika lahan disekitarnya terkonversi; 6) pendapat tentang larangan konversi lahan; 7) upaya perlindungan lahan pertanian oleh pemerintah; 8) pendapat petani untuk bergabung dalam LP2B. Setiap item di dalam kuesioner diberi pilihan respon yang bersifat tertutup (pertanyaan tertutup). Banyaknya pilihan respon yang digunakan adalah 5. Alasannya adalah jika respon terlalu sedikit maka hasilnya terlalu kasar tetapi jika terlalu banyak maka responden sulit membedakannya (Sugiyono, 2010).

\section{Kesesuaian Kriteria Aktual dan Persepsi Petani dalam Perlindungan LP2B}

Berdasarkan kriteria faktual dan persepsi petani, dibuat standar kriteria untuk menentukan kesesuaian wilayah penelitian sebagai kawasan LP2B dan atau sebagai dasar penentuan tingkat proteksi yang harus dilakukan (tinggi dan rendah) berdasar aspek sosial ekonomi. Terdapat sembilan kriteria sosial ekonomi yang digunakan dalam penelitian ini (Lampiran 1). Masing-masing kriteria ditentukan batas kesesuaian dengan standar nilai. Kriteria yang sudah dianalisis kemudian di ranking untuk melihat tingkat kesesuaian wilayah berdasarkan aspek sosial ekonomi. Ranking dilakukan dengan membagi sembilan kategori berdasarkan nilai rata-rata, sehingga diperoleh kategori sebagai berikut;

Kriteria sesuai $\leq 4,5$ kriteria,termasuk prioritas perlindungan tinggi/upaya perlindungan besar

Kriteria sesuai $>4,5$ kriteria,termasuk prioritas perlindungan rendah/upaya perlindungan rendah

\section{Kerangka Pemikiran}

Hasil penelitian Barus et al (2012) di Garut dan Bogor menggunakan GIS dalam pemetaan lahan pangan berkelanjutan, masih menemui beberapa kendala di lapangan, diantaranya; (1) karakteristik ukuran minimum bentangan lahan sawah, (2) karakteristik kawasan, dan (3) keberadaan status kawasan dan kebijakan. Beberapa penelitian lain terkait dengan perlindungan lahan pertanian pangan berkelanjutan juga dilakukan di beberapa daerah. Syamson (2011) melakukan indentifikasi lahan aktual dan potensial untuk tanaman padi sawah yang dapat diusulkan sebagai KP2B di Kabupaten Barru Sulawesi Selatan. Proses deliniasi oleh ekosistem dan penyatuan oleh fasilitas infastruktur berusaha mengusulkan KP2B berdasarkan pertimbangan batas wilayah administrasi kecamatan, kontiguitas spasial dan luas hamparan maksimal. Zulfikar

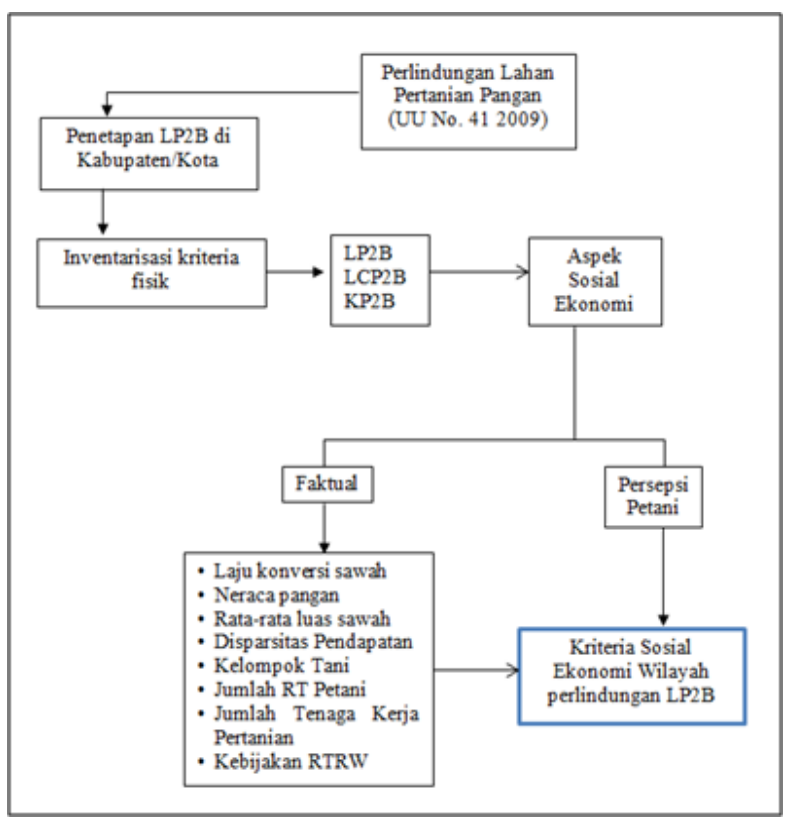

(2012) melakukan penelitian identifikasi potensi lahan sawah untuk arahan perencanaan lahan pertanian pangan berkelanjutan di Kabupaten Pasaman Barat Propinsi Sumatera Barat. Selain mengidentifikasi luas lahan aktual dan potensial untuk tamanan padi, Zulfikar juga melakukan proyeksi kebutuhan lahan sawah dengan beberapa skenario, serta menganalisis pendapat masyarakat tentang faktor yang mempengaruhi perencanaan dan penetapan LP2B dan LCP2B. Di wilayah Jawa Barat, Christina (2011) melakukan penelitian identifikasi potensi lahan sawah untuk mendukung usulan perencanaan lahan pertanian pangan berkelanjutan. Dalam penelitiannya, Christina menetapkan lokasi-lokasi potensial untuk diusulkan sebagai Kawasan Pertanian Pangan Berkelanjutan di tingkat provinsi dan kabupaten serta melakukan analisis kebutuhan lahan sawah yang dihitung berdasarkan proyeksi pertumbuhan penduduk dan kebutuhan pangan.

\section{HASIL DAN PEMBAHASAN}

\section{Kriteria Faktual Perlindungan Lp2b di Kabupaten Kuningan}

Perlindungan Lahan Pertanian Pangan Berkelanjutan (LP2B) didasarkan pada beberapa kriteria fisik dan kriteria sosial ekonomi. Kriteria aspek sosial ekonomi dijadikan sebagai pelengkap kriteria fisik. Kriteria sosial ekonomi perlu diidentifikasi agar proses perlindungan LP2B dapat dilakukan secara komprehensif. Kriteria sosial ekonomi yang digunakan dalam penelitian ini terdiri dari kriteria faktual dan persepsi dari petani sebagai pihak utama yang lahannya akan dilindungi. Kriteria faktual sosial ekonomi di tingkat wilayah kecamatan yang ditetapkan menjadi LP2B terdiri dari; 1) konversi lahan pertanian, 2)rata-rata kepemilikan lahan sawah,3) neraca pangan, 4) ketimpangan pendapatan, 5) kelompok tani, 6) rumah tangga tani, 7) jumlah tenaga kerja pertanian, dan 8) kebijakan RTRW. 
Tabel 2. Luas sawah di lokasi penelitian tahun 20052013

\begin{tabular}{lccc}
\hline Kecamatan & $\begin{array}{c}\text { Rata- } \\
\text { Rata Luas } \\
\text { Sawah (ha) }\end{array}$ & $\begin{array}{c}\text { Rata- } \\
\text { Rata Laju } \\
\text { Konversi } \\
(\%)\end{array}$ & $\begin{array}{c}\text { Rata- } \\
\text { Rata } \\
\text { Luas } \\
\text { Konversi } \\
\text { (ha) }\end{array}$ \\
\hline Cibingbin & $1.497,56$ & $-0,02$ & $-0,25$ \\
Ciawigebang & $2.039,30$ & $-0,60$ & $-11,05$ \\
Cilimus & $1.255,87$ & $-5,47$ & $-124,80$ \\
Kabupaten & $29.100,56$ & $-0,33$ & $-97,00$ \\
Kuningan & & & \\
\hline Sumber : Dinas Pertanian Kabupaten Kuningan 2014
\end{tabular}

\section{Konversi Lahan Pertanian}

Tingkat konversi lahan pertanian sawah merupakan faktor penting yang menjadi dasarpenetapan LP2B di suatu wilayah. Terdapat dua hal mendasar yang menjadi pertimbangan bagaimana proses perlindungan lahan pertanian di suatu wilayah perlu dilakukan terkait dengan tingkat konversi lahan pertanian. Jika tingkat konversi lahan pertanian di suatu wilayah tinggi, luasan lahan pertanian untuk LP2B lebih sedikit karena jika ditetapkan terlalu besar, maka usaha untuk melindungi lahan yang ditetapkan menjadi LP2B juga besar. Sedangkan pada wilayah dengan tingkat konversi yang lebih rendah, luasan lahan untuk LP2B akan lebih besar. Penetapan LP2B dilakukan untuk mempertahankan produksi padi dalam jangka panjang, sehingga penetapan luasan lahan untuk LP2B harus dipertimbangkan dengan baik.

Berdasarkan Tabel 2, laju konversi sawah di Kabupaten Kuningan termasuk rendah. Tanda negatif menunjukkan adanya penurunan luas lahan sawah (sawah terkonversi ke penggunaan lain). Luas konversi ini mencakup lahan sawah yang berpengairan dan non pengairan. Jika dirinci berdasarkan jenis pengairan sawah, laju konversi sawah terbesar untuk sawah dengan irigasi sederhana

Kriteria yang digunakan untuk menilai karakteristik konversi lahandenganmembandingkanlajukonversiditingkatkecamatan dengan laju konversi di tingkat Kabupaten. Mengacu pada Tabel 2, laju konversi di Kecamatan Cibingbin (-0,02\%) nilainya lebih

Tabel 3. Rata-rata luas lahan sawah dan non sawah petani di lokasi penelitian

\begin{tabular}{lcc}
\hline Kecamatan & $\begin{array}{c}\text { Luas Sawah } \\
\text { Petani 2003 } \\
\left(\mathbf{m}^{\mathbf{2}}\right)\end{array}$ & $\begin{array}{c}\text { Luas Sawah } \\
\text { Petani 2013 } \\
\mathbf{( m}^{\mathbf{2}} \mathbf{)}\end{array}$ \\
\hline Cibingbin & $1.041,65$ & $2.629,99$ \\
Ciawigebang & 710,82 & $2.202,88$ \\
Cilimus & 713,83 & $2.185,78$ \\
Kabupaten & 802,15 & $1.728,51$ \\
Kuningan & \multicolumn{2}{|c}{} \\
Sumber: Sensus Pertanian 2013 (Badan Pusat Statistik)
\end{tabular}

Tabel 4. Neraca Pangan di Lokasi Penelitian Tahun $2008-2013$

\begin{tabular}{lcc}
\hline Kecamatan & $\begin{array}{c}\text { Rata-Rata } \\
\text { Produksi Bersih } \\
\text { Padi } \\
\text { (2008 - 2013) } \\
\text { (Ton) }\end{array}$ & $\begin{array}{c}\text { Rasio } \\
\text { Konsumsi } \\
\text { Normatif } \\
\text { terhadap } \\
\text { Produksi } \\
\text { Bersih }\end{array}$ \\
\hline Cilimus & 5.509 & 0,98 \\
Cibingbin & 9.853 & 0,47 \\
Ciawigebang & 13.981 & 0,74 \\
Kabupaten & 215.921 & 0,59 \\
Kuningan & Sumber Kuningan & \\
\hline Dalam Angka 2008-2014(diolah)
\end{tabular}

kecil dari rata-rata laju konversi di tingkat Kabupaten Kuningan (-0,33\%), sedangkan rata-rata laju konversi di Kecamatan Ciawigebang dan Kecamatan Cilimus nilainya lebih besar dari rata-rata laju konversi di Kabupaten Kuningan. Berdasarkan penjelasan tersebut, Kecamatan Cibingbin termasuk wilayah yang sesuai untuk LP2B dari aspek laju konversi lahan, sedangkan Kecamatan Ciawigebang dan Kecamatan Cilimus kurang sesuai. Selain itu, upaya perlindungan LP2B di Kecamatan Cilimus akan membutuhkan upaya yang lebih besar dibandingkan dengan Kecamatan Cibingbin dan Ciawigebang.

\section{Luas Kepemilikan Lahan Sawah}

Kondisi tersebut menunjukkan bahwa luas lahan sawah yang ada jumlahnya terbatas sehingga berdampak terhadap sempitnya rata-rata lahan yang dimiliki oleh petani. Namun petani tetap berusahatani dengan mengoptimalkan lahan sawah yang bisa mereka garap.

Berdasarkan kriteria faktual sosial ekonomi kesesuaian lokasi yang ditetapkan menjadi LP2B mempertimbangkan rata-rata luas lahan sawah yang dimiliki petani. Rata-rata luas kepemilikan lahan sawah di tiga lokasi penelitian (Tabel 3) lebih besar daripada rata-rata luas pemilikan lahan sawah di Kabupaten Kuningan. Mengacu pada kriteria ini, maka ketiga kecamatan di lokasi penelitian ini mempunyai kesesuaian dalam aspek rata-rata kepemilikan lahan sawah.

\section{Neraca Pangan}

Dampak dari adanya konversi lahan adalah penurunan luas tanam yang dapat berdampak terhadap produksi padi. Produksi padi akan berdampak terhadap ketersediaan pangan yang ada di satu wilayah, sehingga proses penentuan wilayah yang akan ditetapkan menjadi LP2B atau Kawasan LP2B harus mempertimbangkan kemampuan suatu wilayah dalam menghasilkan pangan. Produksi pangan dalam hal ini padi dari wilayah yang ditetapkan sebagai kawasan LP2B diharapkan mampu memenuhi kebutuhan pangan penduduk setempat, dan bahkan bisa mengalami surplus produksi.Surplus produksi bisa disimpan atau diekspor untuk memenuhi kebutuhan pangan di wilayah lain. Perlindungan LP2B di lahan sawah seharusnya diutamakan karena produktivitas usahatani padi 
Tabel 5. Ketimpangan Pendapatan Pertanian dan Non Pertanian

\begin{tabular}{|c|c|c|c|}
\hline Kecamatan & $\begin{array}{l}\text { Luas Lahan } \\
\text { (hektar) }\end{array}$ & $\begin{array}{c}\text { Rata - Rata Pendapatan } \\
\text { Usahatani (Rupiah) }\end{array}$ & $\begin{array}{c}\text { Rata - Rata Ketimpangan } \\
\text { Pendapatan }(\%)\end{array}$ \\
\hline \multirow{4}{*}{ Cibingbin } & $<0,20$ & 419.439 & $-58,14$ \\
\hline & $0,20-0,50$ & 855.908 & $-14,58$ \\
\hline & $>0,50-1$ & 1.949 .878 & 94,60 \\
\hline & $>1$ & 2.622 .645 & 161,74 \\
\hline \multirow{4}{*}{ Ciawigebang } & $<0,20$ & 468.258 & $-53,27$ \\
\hline & $0,20-0,50$ & 939.624 & $-6,23$ \\
\hline & $>0,50-1$ & 1.786 .481 & 78,29 \\
\hline & $>1$ & - & - \\
\hline \multirow{4}{*}{ Cilimus } & $<0,20$ & 391.250 & $-60,95$ \\
\hline & $0,20-0,50$ & 911.178 & $-9,06$ \\
\hline & $>0,50-1$ & 1.843 .472 & 83,97 \\
\hline & $>1$ & - & - \\
\hline
\end{tabular}

Keterangan: ${ }^{a}$ Selisih pendapatan usahatani dengan Upah Minimum Kabupaten. UMK Kabupaten Kuningan tahun 2014, Rp. 1.002.000;

Sumber : Hasil Penelitian, 2014

sawah jauh lebih tinggi dibanding usahatani lahan kering (Irawan 2003). Berdasarkan Tabel 4, rasio konsumsi normatif terhadap produksi bersih di dua kecamatan (Cibingbin dan Ciawigebang) yang dijadikan lokasi penelitian nilainya cukup baik, sedangkan di Kecamatan Cilimus nilai rasio konsumsi normatif kurang baik. Nilai rasio konsumsi terhadap produksi yang baik berada di bawah satu, menunjukkan bahwa konsumsi pangan karbohidrat lebih kecil daripada jumlah yang diproduksi. Merujuk pada asumsi tersebut dapat dikatakan Kecamatan Ciawigebang dan Kecamatan Cibingbin merupakan wilayah yang surplus produksi selama lima tahun terakhir.

Kecamatan Ciawigebang merupakan wilayah dengan usulan LP2B terbesar di Kabupaten Kuningan, tetapi tingkat pertumbuhan penduduk di Kecamatan Ciawigebang merupakan yang terbesar diantara kecamatan yang lain. Seperti dikatakan oleh Irawan(2005), akibat pertambahan jumlah penduduk dan peningkatan konsumsi per kapita yang dirangsang oleh peningkatan pendapatan rumah tangga, maka kebutuhan beras terus mengalami peningkatan.

\section{Ketimpangan Pendapatan}

Pendapatan merupakan salah satu unsur yang krusial untuk rumah tangga termasuk rumah tangga pertanian, karena pendapatan yang diperoleh oleh rumah tangga digunakan untuk memenuhi kebutuhan rutin anggota rumah tangga. Selama ini banyak petani yang beralih dan menjual lahan pertanian dikarenakan pendapatan dari sektor pertanian yang kurang memadai untuk mencukupi kebutuhan rumah tangga. Rendahnya pendapatan di sektor pertanian merupakan salah satu hal yang mendorong rendahnya tingkat regenerasi petani di Indonesia. Apalagi persepsi generasi muda perdesaan terhadap profesi petani tidak jauh berbeda dengan persepsi masyarakat perkotaan, yaitu bahwa profesi petani adalah pekerjaan yang kotor, sengsara, dan kurang bergengsi. Kondisi ini menyebabkan lahan pertanian dianggap bukan lagi asset sosial, tetapi lebih diandalkan sebagai aset ekonomi atau modal kerja jika mereka profesi di luar bidang pertanian (Ilham et al, 2004).

Pendapatan yang diperoleh dari sektor pertanian dalam penelitian ini merupakan pendapatan usahatani yang diperoleh dari hasil budidaya padi. Analisis pendapatan non pertanian digunakan pendekatan Upah Minimum Kabupaten. Pada sektor pertanian khususnya on farm pemerintah tidak mengeluarkan tingkat upah minimum, sehingga upah minimum umumnya

Tabel 6. Kelompok tani berdasarkan kelas kemampuan kelompok di lokasi penelitian

\begin{tabular}{lccccc}
\hline \multirow{2}{*}{ Kecamatan } & Jumlah Kelompok Tani & \multicolumn{3}{c}{ Klasifikasi Berdasarkan Kelas } \\
\cline { 3 - 6 } & & 32 & 24 & 1 & Utama \\
\cline { 3 - 6 } & 58 & 60 & 17 & 0 & 0 \\
Cibingbin & 77 & 38 & 22 & - & - \\
Cilimusigebang & 65 & & & & Manjut
\end{tabular}

Sumber: BP4K Kabupaten Kuningan, 2014 


\begin{tabular}{lcccc}
\hline Kecamatan & $\begin{array}{c}\text { Luas Sawah } \\
\text { (hektar) }\end{array}$ & $\begin{array}{c}\text { Jumlah Rumah } \\
\text { Tangga Petani }\end{array}$ & $\begin{array}{c}\text { Jumlah Rumah } \\
\text { Tangga Optimum }\end{array}$ & $\begin{array}{c}\text { Persentase RT Optimum } \\
\text { Terhadap Eksisting (\%) }\end{array}$ \\
\hline Cibingbin & 1.496 & 4.512 & 1.918 & 42,51 \\
Ciawigebang & 2.004 & 5.908 & 4.090 & 69,22 \\
Cilimus & 1.167 & 2.854 & 2.121 & 74,32 \\
Rata-Rata & 1.556 & 4.425 & 2.710 & 61,24 \\
\hline
\end{tabular}

Sumber : Hasil Penelitian dan BPS, 2014

ditetapkan untuk sektor di non pertanian (industri, jasa dan lainnya). Upah Minimum Kabupaten (UMK) ditetapkan berdasar komponen hidup layak di suatu kabupaten/kota. Untuk menunjukkan tingkat kebutuhan hidup yang layak bagi petani maka pendapatan petani dari hasil budidaya padi sawah dibandingkan dengan Upah Minimum Kabupaten. Rata-rata ketimpangan diperoleh dengan membagi pendapatan usahatani dengan pendapatan non usahatani.

Pada usahatani padi sawah rata-rata luas penguasaaan lahan sawah yang dimiliki petani di lokasi penelitian relatif sempit. Berdasarkan Tabel 5, untuk luas lahan kurang dari 0,20 hektar ketiga kecamatan mempunyai ketimpangan pendapatan dengan nilai negatif yang besar (> 50\%). Sedangkan luas lahan yang lebih dari atau sama dengan 0,20 hektar mempunyai ketimpangan pendapatan yang lebih sedikit.

Persentase ketimpangan pendapatan negatif menunjukkan pendapatan usahatani nilainya lebih kecil daripada pendapatan non pertanian(UMK). Pada ketiga daerah penelitian pemilikan lahan usahatani yang sempit menyebabkan pendapatan yang diperoleh dari usahatani nilainya kecil. Hasil ini konsisten dengan hasil penelitian LPEM-UI (2004) yang menyatakan terdapat korelasi yang kuat antara skala penguasaan lahan dengan indeks kemiskinan dan indeks rumpang kemiskinan (poverty gap). Semakin luas penguasaan lahan, makin rendah tingkat kemiskinan. Selain itu data terbaru dari Sensus Pertanian tahun 2013 menunjukkan bahwa rata-rata pendapatan petani di Indonesia adalah 1 juta rupiah per bulan, yang berarti berada di bawah UMK (BPS 2014).

Petani di lokasi penelitian tidak hanya mengandalkan pendapatan dari sektor pertanian (sawah). Petani mempunyai pendapatan di luar bidang pertanian (non farmincome) sebagai strategi bertahan hidup. Hal ini diungkapkan oleh salah seorang responden petani di Kecamatan Cibingbin.

"Jika hanya mengandalkan dari hasil sawah, hanya cukup untuk memenuhi kebutuhan pokok. Apalagi sawah hanya bisa ditanami maksimal dua kali dalam setahun. Saat musim kemarau saya biasa menjadi kuli bangunan di Jakarta, lumayan untuk menambah pendapatan." (Pak KSA 50 tahun)

\section{Kelompok Tani}

Perlindungan LP2B pada suatu wilayah selain didukung dengan ketersediaan infrastruktur pertanian yang memadai, juga perlu mendapat dukungan dari aspek sosial. Aspek sosial yang mendukung dalam upaya perlindungan LP2B diantaranya adalah adanya kelompok tani, jumlah penduduk

Tabel 8. Rencana Tata Ruang Wilayah tahun 2011-2030 di Lokasi Penelitian

\begin{tabular}{clccc}
\hline \multirow{2}{*}{ No } & \multirow{2}{*}{ Kriteria Kawasan Rencana Tata Ruang Wilayah } & \multicolumn{3}{c}{ Kecamatan } \\
\cline { 3 - 5 } & & Cibingbin & Ciawigebang & Cilimus \\
\hline 1 & Strategis Provinsi & $\mathrm{V}$ & $\mathrm{V}$ & $\mathrm{V}$ \\
2 & Strategis Kabupaten & $\mathrm{X}$ & $\mathrm{X}$ & $\mathrm{V}$ \\
3 & Pariwisata & $\mathrm{X}$ & $\mathrm{X}$ & $\mathrm{V}$ \\
4 & Agroindustri & $\mathrm{X}$ & $\mathrm{X}$ & $\mathrm{V}$ \\
5 & Pembangunan Waduk & $\mathrm{V}$ & $\mathrm{V}$ & $\mathrm{X}$ \\
6 & Resapan Air & $\mathrm{X}$ & $\mathrm{X}$ & $\mathrm{V}$ \\
7 & Taman Nasional & $\mathrm{X}$ & $\mathrm{X}$ & $\mathrm{V}$ \\
8 & Berfungsi Lindung & $\mathrm{X}$ & $\mathrm{X}$ & $\mathrm{V}$ \\
9 & Peruntukan Tanaman Pangan & $\mathrm{V}$ & $\mathrm{V}$ & $\mathrm{V}$ \\
10 & Peruntukan Hortikultura & $\mathrm{X}$ & $\mathrm{X}$ & $\mathrm{V}$ \\
11 & Perkebunan & $\mathrm{V}$ & $\mathrm{V}$ & $\mathrm{V}$ \\
12 & Pertambangan Mineral & $\mathrm{V}$ & $\mathrm{V}$ & $\mathrm{X}$ \\
\hline Keterangan $:$ V = iya, X tidak
\end{tabular}

Keterangan : $\mathrm{V}=$ iya, $\mathrm{X}=$ tidak

Sumber : Bappeda, 2011 
Tabel 9. Hasil analisis skor persepsi petani

\begin{tabular}{lccccc}
\hline & \multicolumn{5}{c}{ Skor } \\
\cline { 2 - 6 } Kecamatan & N1 & N2 & N3 & N4 & N5 \\
\cline { 2 - 6 } & 480 & 960 & 1440 & 1920 & 2400 \\
\cline { 2 - 5 } & Min & $\begin{array}{c}\text { Kuar- } \\
\text { til I }\end{array}$ & $\begin{array}{c}\text { Me- } \\
\text { dian }\end{array}$ & $\begin{array}{c}\text { Kuar- } \\
\text { til III }\end{array}$ & Maks \\
\hline Cibingbin & \multicolumn{5}{c}{1063} \\
Ciawi \\
gebang \\
Cilimus & \multicolumn{5}{c}{1092} \\
Sumber: Hasil Penelitian (2014)
\end{tabular}

yang bekerja di sektor pertanian dan atau jumlah rumah tangga petani di suatu wilayah. Kelompok tani yang ada pada suatu wilayah termasuk dukungan dari aspek sosial mengingat selama ini kelompok tani menjadi corong dalam setiap program pemerintah maupun swasta yang dilakukan untuk petani. Sebagai media untuk penyebaran informasi dan perantara pelaksanaan program, kelompok tani diharapkan dapat melakukan pembinaan terhadap petani sehingga petani dapat meningkat kesejahteraannya.

Insentif yang diberikan dalam perlindungan LP2B tidak semuanya diberikan kepada individu petani, tetapi banyak insentif yang sifatnya diberikan secara kewilayahan atau sumber daya bersama seperti infrastruktur pertanian dan alat mesin pertanian.Insentif yang diberikan secara wilayah difasilitasi melalui kelompok, sehingga kemampuan kelompok tani dapat menunjukkan kesiapan suatu wilayah dalam menerima insentif. Berdasarkan Tabel 6, di ketiga kecamatan sebagian besar kelompok tani masih berada pada tahapan pemula, hanya di Kecamatan Cibingbin yang terdapat kelompok tani dengan kelas kemampuan kelompok madya dan utama. Berdasarkan kriteria dari aspek kelompok tani, suatu wilayah dikatakan sesuai untuk pengembangan LP2B jika jumlah kelompok tani pemula kurang dari 50\%. Dengan kata lain, jumlah kelompok tani pada kelas lanjut, madya dan utama jumlahnya harus lebih besar dari kelas pemula. Jika mengacu pada kriteria tersebut, maka ketiga kecamatan di lokasi penelitian kurang sesuai untuk menjadi lokasi LP2B berdasarkan aspek kelompok tani.

Berdasarkan Permentan Nomor 82 Tahun 2013, kelompok tani pada kelas pemula menunjukkan kualitas kelompok tani yang masih rendah sehingga perlu dilakukan pembinaan dan upaya peningkatan kapasitas agar bisa mendukung kesejahteraan anggotanya. Dengan kondisi tersebut, maka dalam proses perlindungan LP2B perlu diperhatikan aspek pembinaan kelompok tani dalam rangka pemberian insentif dan peningkatan kapasitas petani. Rendahnya kualitas kelompok tani diakui oleh seorang penyuluh di Kecamatan Cilimus yang menyatakan.

\section{Rumah Tangga Pertanian Optimum}

Jumlah rumah tangga pertanian pada wilayah yang akan ditetapkan menjadi LP2B menjadi pertimbangan penting terkait dengan siapa yang akan mengelola lahan pertanian di wilayah tersebut ketika LP2B sudah ditetapkan. Jumlah rumah tangga pertanian di tiga kecamatan penelitian mengalami penurunan dari tahun 2003 sampai tahun 2013 (BPS, 2013). Persentase penurunan jumlah rumah tangga pertanian di Kecamatan Ciawigebang dan Kecamatan Cilimus lebih besar daripada persentase penurunan rumah tangga pertanian di tingkat kabupaten. Menurunnya jumlah rumah tangga pertanian diikuti dengan penurunan rumah tangga petani gurem di seluruh kecamatan penelitian. Persentase rumah tangga petani gurem di ketiga lokasi penelitian mendominasi jumlah rumah tangga pertanian (lebih dari 80\%).

Tabel 7 menunjukkan luas lahan optimum untuk memenuhi kebutuhan hidup layak bagi petani.Luas lahan sawah yang optimum menjadi dasar untuk penentuan jumlah rumah tangga petani yang optimum di lokasi penelitian.Luas lahan optimum dianalisis dengan pendekatan pengeluaran untuk memenuhi kebutuhan hidup layak (Nazam et al 2001). Pada penelitian ini kebutuhan hidup layak didekati dengan komponen perhitungan Upah Minimum Kabupaten Kota. Kebutuhan hidup layak per bulan tersebut kemudian digeneralisasi untuk kebutuhan hidup layak per tahun kemudian dihitung dengan pendapatan dari usahatani padi. Berdasarkan hasil penelitian luas lahan optimum sesuai kebutuhan hidup layak sebesar 0,78 hektar di Kecamatan Cibingbin, 0,49 hektar di Kecamatan Ciawigebang dan 0,55 hektar di Kecamatan Cilimus. Jumlah RT pertanian di lokasi penelitian lebih besar dibandingkan dengan ketersediaan lahan yang ada.

Fenomena kurangnya lahan pertanian untuk menopang kebutuhan layak petani menunjukkan ada peningkatan kepadatan agrararis. Sihaloho et al (2007) menyebutkan kepadatan agraris mengalami peningkatan bisa terjadi karena pertambahan jumlah petani maupun berkurangnya akses terhadap lahan. Implikasi terbatasnya lahan adalah perubahan pola nafkah agraria dari pertanian ke non pertanian. Dalam penelitian ini terjadi penurunan jumlah petani, jika mengacu pada hasil penelitian Sihaloho maka kurangnya luas lahan optimum dapat terjadi karena kurangnya akses terhadap lahan. Terkait dengan kriteria rumah tangga optimum pada persentase rumah tangga optimum terhadap lahan dengan jumlah lebih dari $50 \%$ termasuk dalam kategori sesuai. Kecamatan Ciawigebang dan Kecamatan Cilimus termasuk dalam kategori sesuai, karena persentase RT petani optimum terhadap luas lahan lebih dari 50\%. Kecamatan Cibingbin termasuk dalam kategori kurang sesuai karena persentase RT petani optimum terhadap luas lahan kurang dari $50 \%$. Kriteria rumah tangga optimum digunakan sebagai dasar untuk melihat tingkat kepadatan agaria di wilayah yang ditetapkan LP2B, sehingga dapat disusun arahan kebijakan yang sesuai utamanya dalam memenuhi kebutuhan hidup layak petani.

\section{Tenaga Kerja Pertanian}

Wilayah yang ditetapkan menjadi LP2B perlu mempertimbangkan kontribusi sektor pertanian terhadap perekonomian di wilayah yang salah satunya ditunjukkan oleh sumbangan tenaga kerja 
Tabel 9. Hasil analisis kesesuaian lokasi LP2B berdasarkan aspek sosial ekonomi

\begin{tabular}{|c|c|c|c|c|}
\hline No & Kriteria & Kecamatan Cibingbin & Kecamatan Ciawigebang & Kecamatan Cilimus \\
\hline 1 & Konversi Lahan & $\mathrm{V}$ & $\mathrm{X}$ & $\mathrm{X}$ \\
\hline 2 & Neraca Pangan & V & $\mathrm{X}$ & $\mathrm{X}$ \\
\hline 3 & $\begin{array}{l}\text { Rata-Rata Luas } \\
\text { Pemilikan Lahan } \\
\text { Sawah }\end{array}$ & V & V & $\mathrm{V}$ \\
\hline 4 & $\begin{array}{l}\text { K e t i m p a n g a n } \\
\text { Pendapatan }\end{array}$ & V & $\mathrm{X}$ & $\mathrm{X}$ \\
\hline 5 & $\begin{array}{l}\text { Jumlah RT Petani } \\
\text { Optimum }\end{array}$ & $\mathrm{X}$ & V & V \\
\hline 6 & $\begin{array}{l}\text { Jumlah Tenaga } \\
\text { Kerja Pertanian }\end{array}$ & V & $\mathrm{X}$ & V \\
\hline 7 & Kelompok Tani & $\mathrm{X}$ & $\mathrm{X}$ & $\mathrm{X}$ \\
\hline 8 & RTRW & V & V & $\mathrm{X}$ \\
\hline 9 & Persepsi Petani & V & $\mathrm{V}$ & $\mathrm{V}$ \\
\hline \multicolumn{2}{|c|}{ Jumlah Sesuai } & 7 & 4 & 4 \\
\hline
\end{tabular}

Keterangan : $\mathrm{V}=$ sesuai, $\mathrm{X}=$ tidak sesuai

Sumber : Hasil Penelitian, Bappeda, dan BPS, 2014

yang dapat diserap sektor pertanian. Pada tahun 2012 penduduk yang bekerja di sektor pertanian di Kabupaten Kuningan sebesar $32,66 \%$, sedangkan persentase penduduk yang bekerja di luar sektor pertanian didominasi oleh sektor perdagangan (28,02\%). Proporsi tenaga kerja yang bekerja di sektor pertanian mencapai $54,64 \%$ di Kecamatan Cilimus, sementara di Kecamatan Cibingbin dan Ciawigebang masing-masing 35,47\% dan 26,66\%. Ketergantungan penduduk yang tinggi terhadap lahan pertanian dapat menjadi faktor kuat untuk mendukung LP2B. Sumbangan tenaga kerja yang diserap sektor pertanian menunjukkan kontribusi terhadap perekonomian wilayah (Irawan 2008).

Kriteria yang digunakan untuk menentukan kesesuaian lokasi berdasarkan kriteria jumlah tenaga kerja adalah lokasi dikatakan sesuai jika persentase penduduk yang bekerja di sektor pertanian jumlahnya lebih besar daripada persentase di tingkat kabupaten. Berdasarkan kriteria tenaga kerja pertanian, Kecamatan Cibingbin dan Kecamatan Cilimus termasuk dalam kategori sesuai, sedangkan Kecamatan Ciawigebang termasuk dalam kategori kurang sesuai untuk penetapan LP2B.

\section{Kebijakan Rencana Tata Ruang Wilayah (RTRW)}

Penetapan lokasi dan luas LP2B harus sesuai dengan peraturan daerah dan atau rencana lainnya yang mengatur mengenai penggunaan ruang khususnya. Peraturan Daerah (perda) Kabupaten Kuningan Nomor 26 tahun 2011 mengatur mengenai Rencana Tata Ruang Wilayah Kabupaten Kuningan Tahun 2011-2031. Dalam Perda tersebut diatur mengenai rencana penetapan LP2B di Kabupaten Kuningan seluas 11.706 hektaryang mencakup 32 kecamatan. Penetapan luasan LP2B dalam perda ini masih dalam proses revisi karena luas lahan aktual sawah yang ada saat ini mencapai 29.000 hektar, sehingga seharusnya luas LP2B yang ditetapkan luasnya dapat lebih besar. Penjabaran Perda RTRW menjelaskan mengenai arahan penggunaan kawasan di Kabupaten Kuningan. Dalam konteks penelitian ini, arahan RTRW yang akan di kaji terfokus di tiga kecamatan yang menjadi lokasi penelitian yaitu Kecamatan Cibingbin, Kecamatan Ciawigebang dan Kecamatan Cilimus.

Aspek kebijakan RTRW termasuk dalam kriteria faktual yang menjadi dasar penetapan LP2B. Kriteria ini menjelaskan jika arahan penggunaan ruang di lokasi penelitian spesifik dan tidak banyak arahan pemanfaatan ruang di luar sektor pertanian termasuk kategori sesuai. Berdasarkan Tabel 8, Kecamatan Cilimus merupakan kecamatan yang kurang sesuai untuk penetapan LP2B. Dari 12 kriteria kawasan terdapat 10 kriteria kawasan di Kecamatan Cilimus, dengan demikian terdapat potensi tumpang tindih kawasan dan atau fungsi dari satu kawasan berkurang. Banyak terdapat arahan penggunaan ruang di luar peruntukan tanaman pangan di Kecamatan Cilimus. Kecamatan Cibingbin dan Kecamatan Ciawigebang termasuk kategori sesuai karena dari arahan penggunaan ruang, masih didominasi pengembangan sektor pertanian serta tidak banyak arahan penggunaan untuk kawasan lain.

\section{Kriteria Persepsi dalam Perlindungan Lp2b di Kabupaten Kuningan}

Persepsi petani terhadap LP2B merupakan salah satu unsur yang harus diperhatikan karena petani merupakan pihak utama yang akan menentukan terlaksananya upaya perlindungan lahan pertanian pangan berkelanjutan. Zakaria dan Rachman (2013) menyatakan bahwa implementasi LP2B sangat tergantung dari dukungan dan partisipasi petani. Hasil analis persepsi menunjukkan petani di tiga kecamatan mendukung pelaksanaan LP2B. Respon positif petani ditunjukkan dengan rentang skor persepsi yang berada diantara kuartil 1 dan median, sehingga secara umum upaya perlindungan LP2B dapat dilaksanakan di tiga kecamatan ini.

Secara individu, dari 8 pertanyaan yang ditanyakan untuk 
item pertanyaan pertama tentang peran lahan pertanian yang diusahakan, 99\% responden menyatakan lahan pertanian sangat penting untuk menopang penyediaan pangan dan pendapatan rumah tangga. Seperti diungkapkan oleh responden petani.

"Lahan sawah ini warisan dari orang tua bapak, kalau untuk memenuhi kebutuhan pokok keluarga lumayan,tidak perlu beli beras, malah kalau ada lebihnya bisa dijual." (Pak SJI 50 tahun)

"Bapak bisanya cuman kuli, tidak ada bakat lain, jadi ya sawah ini jadi pegangan bapak untuk menafkahi keluarga. Walaupun tidak selalu cukup dari sawah tapi bisa jadi nambah-nambah kebutuhan keluarga." (Pak PLG 46 tahun)

"Kalau punya sawah, walaupun kecil rasanya tenang karena tidak harus mikir cari beras untuk makan, minimal untuk keluarga ada, syukur ada lebihnya." (Pak LSJ 35 tahun)

Pernyataan tersebut menunjukkan bahwa petani sadar dengan adanya proses konversi lahan disatu lokasi dapat mendorong lahan sawah lainnya di sekitar lokasi tersebut terancam. Tanpa ada upaya untuk meredam konversi maka lahan-lahan sawah produktif lainnya bisa hilang. Padahal petani masih menginginkan lahan sawah mereka tetap dilokasi tersebut. Sesuai dengan hasil wawancara, terdapat $56 \%$ responden di ketiga lokasi penelitian yang ingin mempertahankan lahan yang di usahakan saat ini, dimana $23 \%$ di antaranya menjawab dengan pasti.

Item pertanyaan mengenai rencana petani untuk melakukan konversi lahan sawah yang diusahakan menjadi penggunaan lain mendapat mendapat penolakan dari 35\% di tiga lokasi penelitian yang menunjukkan petani tidak mempunyai rencana untuk melakukan konversi lahan. Terdapat 21\% responden mempunyai rencana untuk melakukan konversi lahan, sebagian besar alasannya untuk dijadikan bangunan rumah bagi anak. Dorongan konversi dan atau menjual lahan pertanian dipengaruhi oleh lingkungan sekitar, ketika lahan sawah di sekitar sudah banyak dialih fungsikan maka lahan sawah yang tersisa akan mendapat tekanan yang sangat besar. Hal ini tercermin dari pernyataan responden petani di lokasi penelitian.

"Biasanya petani disini kalau disekitar lahan sawahnya sudah mulai berdiri rumah, sawahnya dijdadikan lahan kering karena pasti banyak gangguan hewan ternak kalau sudah dekat rumah." (Pak WLM 45 tahun)

"Kalau untuk menjual lahan sawah sepertinya tidak, karena lahan ini buat simpanan keluarga, barangkali nanti anak butuh untuk buat rumah, jadi tidak susah cari lahan." (Pak DDM 53 tahun)

Kesesuaian Kriteria Aktual dan Persepsi Petani dalam Perlindungan Lp2b

Setelah dijabarkan mengenai kriteria aktual dan persepsi yang ada di lokasi penelitian. Selanjutnya dilakukan sintesis terhadap hasil analisis tersebut, sintesis dilakukan untuk melihat kesesuaian suatu lokasi LP2B dari aspek sosial ekonomi. Kriteria sosial ekonomi yang menjadi dasar untuk penentuan kesesuaian ini dijelaskan pada masing-masing bagian di pembahasan sebelumnya. Berdasarkan kriteria tersebut, hasil analisis di ketiga kecamatann selanjutnya diindentifikasi dan dianalisis kesesuaian wilayah sebagai kawasan LP2B berdasarkan aspek sosial ekonomi. Kriteria sosial ekonomi ini digunakan untuk melengkapi kriteria fisik dan diharapkan dapat menjadi dasar untuk menentukan wilayah prioritas dalam perlindungan LP2B. Hasil analisis kesesuaian ditampilkan dalam Tabel 9.

Kriteria sosial ekonomi perlu menjadi pertimbangan karena lahan pertanian memiliki manfaat baik secara sosial dan ekonomi maupun lingkungan. Menurut Iqbal (2007) secara ekonomi, lahan pertanian adalah masukan paling esensial dalam keberlangsungan proses produksi. Secara sosial, eksistensi lahan pertanian terkait dengan tatanan kelembagaan masyarakat petani dan aspek budaya lainnya Berdasarkan aspek lingkungan, aktivitas pertanian pada umumnya relatif lebih selaras dengan prinsip-prinsip pelestarian lingkungan.

\section{KESIMPULAN DAN SARAN}

\section{Kesimpulan}

Berdasarkan hasil analisis terhadap sembilan kriteria faktual sosial ekonomi lahanLP2B di Kabupaten Kuningan, yaitu; tingkat konversi lahan, neraca pangan, ketimpangan pendapatan usahatani dan non usahatani, jumlah rumah tangga pertanian, jumlah tenaga kerja pertanian, status kepemilikan lahan, kelompok tani dan kebijakan RTRW terdapat perbedaan kesesuaian sosial ekonomi diantara tiga kecamatan yang dianalisis. Dari kriteria persepsi, petani di lokasi penelitian mempunyai persepsi yang positif terhadap program LP2B. Petani di tiga kecamatan mendukung pelaksanaan program LP2B. Petani di lokasi penelitian merasa perlu ada upaya perlindungan terhadap lahan pertanian yang digarap oleh petani saat ini. Petani menganggap lahan pertanian yang diusahakan saat ini sangat penting untuk mendukung penyediaan pangan dan sumber pendapatan keluarga.Hasil sintesis kesesuaian lokasi berdasarkan kriteria sosial ekonomi, Kecamatan Cibingbin mempunyai kesesuaian paling tinggi sehingga termasuk kategori perlindungan rendah. Kecamatan Cilimusdan Kecamatan Ciawigebang dengan empat kriteria yang sesuai termasuk kategori perlindungan tinggi yang akan membutuhkan upaya perlindungan besar.

\section{Saran}

1. Pemerintah Kabupaten Kuningan sebaiknya memasukan kesesuaian kriteria sosial ekonomi untuk melengkapi kriteria fisik lahan yang akan dijadikan LP2B, sehingga penentuan lokasi LP2B didasarkan pada kriteria yang komprehensif.

2. Proses sosialisasi dan penerapan progam LP2B perlu melibatkan petani untuk mengakomodir keinginan petani terkait proses perlindungan LP2B termasuk hak dan kewajiban petani yang melindungi lahannya. 
3. Indikator keseuaian sosial ekonomi yang dianalisis dalam penelitian ini mempunyai bobot yang sama untuk setiap kriteria, padahal masing-masing kriteria memiliki pengaruh yang berbeda dalam mendukung upaya penetapan LP2B. Oleh karena itu perlu dilakukan perbaikan indikator dengan memberikan bobot untuk masing-masing indikator kesesuaian sosial ekonomi.

\section{DAFTAR PUSTAKA}

Badan Pertanahan Nasional. 2009. Rencana Tata Ruang Wilayah(RTRW) 2008. Jakarta(ID) Badan Pertanahan Nasional.

[Bappeda Kabupaten Kuningan]. Badan Perencanaan Pembangunan Daerah Kabupaten Kuningan. 2012. Data Sosial Ekonomi Daerah Kabupaten Kuningan Tahun 2012. Kuningan(ID): BPS, Bappeda Kabupaten Kuningan.

Barus B, Panuju DR, Munibah K, Iman LS, Trisasongko BH, Widiana N, Kusumo R. 2012. Model Pemetaan Sawah dan Perlindungan Lahan Pertanian Pangan dengan Penginderaan Jauh dan Sistem Informasi Geografis (Model of Rice Field Mapping and It's Protection using Remote Sensing and GIS). Seminar dan Ekspose Hasil Kegiatan dan Penelitian P4W LPPM-IPB. 2012 Des 11; Bogor, Indonesia.

[BPS Kabupaten Kuningan]. Badan Pusat Statistik Kabupaten Kuningan. 2009. Kabupaten Kuningan dalam Angka. Kuningan (ID): BPS Kabupaten Kuningan.

[BPS Provinsi Jawa Barat]. Badan Pusat Statistik Provinsi Jawa Barat. 2011. Jawa Barat dalam Angka. Bandung (ID): BPS Provinsi Jawa Barat.

ChristinaDR. 2011. Identifikasi Lahan Potensial untuk Mendukung Usulan Perencanaan Lahan Pertanian Pangan Berkelanjutan (Studi Kasus di Provinsi Jawa Barat) [Tesis]. Bogor (ID): Institut Pertanian Bogor.

[Dirjen PSP Kementan]. Direktorat Jenderal Sarana dan Prasarana Kementerian Pertanian. 2013. Kajian Hasil Inventarisasi LP2B Kab. Majalengka, Purbalingga, Gunung Kidul, Madiun. Jakarta (ID): Dirjen PSP Kementan.

[Disperta Kabupaten Kuningan]. Dinas Pertanian Kabupaten Kuningan. 2013. Laporan Inventarisasi LP2B (ID): Disperta Kabupaten Kuningan

Firman T. 2004. Major issues in Indonesia's urban land development. Land Use Policy. 21(2004): 347-355.

Furuseth OJ,Pierce JT.1982. A Comparative Analysis of Farmland Preservation Programmes in North America. The Canadian Geographer. 26(3): 191-206.

Gasperz, Vincent. 1991. Teknik Penarikan Contoh untuk Penelitian Survei. Bandung (ID): Penerbit-Tarsito.

Handari MFAW. 2012. Implementasi Kebijakan Perlindungan Lahan Pertanian Pangan Berkelanjutan Di Kabupaten Magelang [Tesis]. Semarang (ID): Universitas Diponegoro

Ilham Nyak, Yusman S, Supena F. 2004. Perkembangan dan Faktor-Faktor yang Mempengaruhi Konversi Lahan Sawah serta Dampak Ekonominya.

Iqbal, M. 2007. Fenomena dan Strategi Kebijakan Pemerintah Daerah dalam Pengendalian Konversi Lahan Sawah di Provinsi Bali dan Nusa Tenggara Barat. Analisis
Kebijakan Pertanian. 5(4):287-303

Irawan B.2005. Konversi Lahan Sawah: Potensi Dampak, Pola Pemanfaatannya, dan Faktor Determinan. Forum

Penelitian Agro Ekonomi. 23(1): 1-18.

Irawan B.2008. Meningkatkan Efektivitas Kebijakan Konversi Lahan. Forum Penelitian Agro Ekonomi. 26(2): 116-131.

Juanda, Bambang. 2009. Ekonometrika: Pemodelan dan Pendugaan. Bogor (ID): IPB Press.

Lefroy Rod D.B, Hans-Dieter B, Mohammad R. 2000. Indicator Sustainable Land Management Based on Farmer Surveys in Vietnam, Indonesia, and Thailand. Agriculture, Ecosystems and Environment. 81(2000): 137-146.

Lichtenberg E, Ding C. 2008. Assessing farmland protection policy in China. Land Use Policy. 25(2008): 59-68.

Nasoetion, L. dan J. Winoto. 1996. Masalah Alih Fungsi Lahan Pertanian dan Dampaknya terhadap Keberlangsungan Swasembada Pangan. Prosiding lokakarya "Persaingan dalam Pemanfaatan Sumberdaya Lahan dan Air": Dampaknya terhadap Keberlanjutan Swasembada Beras: 64 - 82. Hasil Kerja sama Pusat Penelitian Sosial Ekonomi Pertanian dengan Ford Foundation. Bogor, Indonesia.

Nazam M, Sabiham S, Pramudya B, Widiatmaka, Rusastra I.W. 2011. Penetapan Luas Optimum Usahatani Padi Sawah Mendukung Kemandirian Pangan Berkelanjutan di Nusa Tenggara Barat. Jurnal Agro Ekonomi. 29(2): 113-145.

Rachman B, Zakaria AK, Suharyono S. 2012. Laporan Akhir Penelitian TA 2012; Insentif Ekonomi dan Apek Kelembagaan untuk Mendukung Implementasi Undang-Undang Perlindungan Lahan Pertanian Pangan Berkelanjutan. Jakarta (ID): Pusat Analisis Sosial Ekonomi dan Kebijakan Pertanian, Badan Penelitian dan Pengembangan Pertanian, Kementerian Pertanian.

Rustiadi E. 2001. Alih Fungsi Lahan Dalam Perspektif Lingkungan Perdesaan. Lokakarya Penyusunan Kebijakan dan Strategi Pengelolaan Lingkungan Kawasan Perdesaan. 2001 Mei 10-11; Bogor, Indonesia.

Sihaloho M, Dharmawayan Arya H, Rusli Said. 2007. Konversi Lahan Pertanian dan Perubahan Struktur Agraria. Sodality : Jurnal Transdisiplin Sosiologi, Komunikasi, dan Ekologi Manusia. 1(2007).

Sudaryanto T, Rusastra I W. 2006. Kebijakan Strategis Usaha Pertanian dalam Rangka Peningkatan Produksi dan Pengentasan Kemiskinan. Jurnal Litbang Pertanian. $25(4)$.

Sugiyono. 2010. Metode Penelitian Kuantitatif Kualitatif dan R\&D. Bandung (ID): Alfabeta. 